\begin{tabular}{lc}
\hline & ANNALES \\
& UNIVERSITATIS MARIAE CURIE-SKLODOWSKA \\
LUL. V & SECTIO N \\
\hline
\end{tabular}

ISSN: 2451-0491 • e-ISSN: 2543-9340 • CC-BY 4.0 • DOI: 10.17951/en.2020.5.359-372

\title{
Stawanie się człowieka pogranicza
}

\section{Becoming a Borderland Human}

\author{
Renata M. Sigva \\ Uniwersytet Jagielloński w Krakowie. Wydział Filozoficzny \\ ul. Gołębia 24, 31-007 Kraków, Polska \\ renata.sigva@uj.edu.pl \\ https://orcid.org/0000-0001-5622-3631
}

\begin{abstract}
The article discusses categories of becoming in the philosophical and pedagogical context. Becoming is a feature of a borderland man living in a multicultural world. The borderland was defined and the features of a person living on this borderland have been indicated. The borderland unit is dynamic, it crosses both territorial and axiological boundaries, it just becomes.
\end{abstract}

Keywords: becoming; borderland; borderland man; multicultural world

\begin{abstract}
Abstrakt. W artykule omówiono kategorie stawania się w kontekście filozoficzno-pedagogicznym. Stawanie się jest cechą człowieka pogranicza żyjącego w świecie wielokulturowym. Zdefiniowano pogranicze i wskazano, jakie cechy ma człowiek żyjący na owym pograniczu. Jednostka pogranicza jest dynamiczna, przekracza granice zarówno terytorialne, jak i aksjologiczne, po prostu się staje.
\end{abstract}

Słowa kluczowe: stawanie się; pogranicze; człowiek pogranicza; świat wielokulturowy 


\section{WPROWADZENIE}

Język współczesnej pedagogiki i filozofii nie ogranicza się do pojęć i wychodzi poza ich modernistyczną zamkniętą strukturę w stronę polisemantycznych i teoriotwórczych kategorii. I choć kategorie, definiowane przez Arystotelesa jako pewne sposoby orzekania o podmiotach oraz ich klasyfikowania, stanowią ponadczasowy trend, to poddały się one procesowi zmiany w kierunku aprioryczności i dynamiczności oraz dialektycznej optyce (Skarga 2005). Każda kategoria badawcza przynależąca do danej dyscypliny jest skutkiem rozwoju tej nauki, ale zawiera też wymiar interdyscyplinarny. Tak rzecz tę ujmuje Barbara Skarga: „[...] kategoria pełni dwoistą funkcję. Kształtuje pole teoretycznych badań, wyznaczając problemy, tkwiąc jednak jakby w centrum tego pola stanowi również przedmiot analiz. Jest bowiem strukturą polisemiczną, wiąże w sobie niejeden sens, a niekiedy wiele sensów" (tamże: 110). Stawanie się odnajdujemy w płaszczyźnie myślenia zarówno filozoficznego, jak i pedagogicznego.

Stawanie się jest podstawową kategorią w nurcie myślowym określanym ogólnie jako filozofia procesu. Jest to nurt wielowątkowy, pełen wewnętrznych sporów, a główną tezę można wyrazić w stwierdzeniu, że ostatecznym prawem czy rdzeniem bytu jest stawanie się, skutkujące twórczą przemianą jednostki. W stawaniu się każdego człowieka uczestniczą zawsze elementy subiektywne, ponieważ nie ma procesu poza jego przedstawieniem. Sama subiektywność jednak nie mogłaby zaistnieć, gdyby nie wchodziła w żadne związki z tym, co obiektywne. Człowiek się staje zawsze w jakichś warunkach, okolicznościach, zawsze w jakimś społeczeństwie.

Starożytny filozof Heraklit wskazywał, że byt jako taki nie istnieje, a jest tylko jego stawanie się, przemijanie jako ciągłe przechodzenie z jednego stanu w inny (Tatarkiewicz 1998). Kontynuacją tej zmienności rzeczy jest m.in. kreacjonistyczna koncepcja bytu Georga W.F. Hegla. Ten żyjący na przełomie XVIII i XIX wieku niemiecki filozof twierdził, że byt w swojej naturze jest zmienny, rozwija się, tworzy, ewoluuje (Żelazny 2000). Zdaniem tego uczonego to właśnie z pojęcia bytu wyłania się pojęcie stawania. Jest to logiczna kontynuacja ewolucjonizmu człowieka - nie można tylko być, człowiek musi się jeszcze sam urzeczywistniać, definiować siebie, poznawać. Ale to nie wszystko, u Hegla odnajdujemy bowiem jeszcze potrzebę świadomości samego siebie. Owa świadomość własnego ja ukryta jest w duchu i poprzez to pojęcie Hegel próbuje wyjaśnić byt, który pojmowany w całości jest absolutem. Mówiąc językiem współczesnym, absolut jest procesem własnego stawania się - staje się konkretny lub rzeczywisty tylko przez własny rozwój (Magee 2000). 
Pojęcie stawania się, ewolucji jest jednym z istotnych punktów ontologii Alfreda N. Whiteheada. „Przyroda nie stoi nigdy w miejscu, cechuje ją ciągłe przepływanie: powstaje w niej ciągle coś nowego, jest w niej postęp twórczy" (Tatarkiewicz 1998: 323). W ujęciu Whiteheada byty są dwoiste, zarówno te aktualne, jak i wieczne, natomiast stosunek pomiędzy bytami aktualnymi a obiektami wiecznymi jest taki, jak między możnością a aktem. Byty aktualne są jednostkami doświadczenia. $Z$ jednej strony, dzięki wewnętrznym relacjom, stanowią one źródło czasu i przestrzeni, z drugiej zaś mogą się w czasie i przestrzeni przejawiać. Aktualne byty - nazwane też aktualnymi zaistnieniami - są podstawowymi realnymi rzeczami, z których składa się świat (Grzmot-Bilski 1996). A więc kto się staje? Janusz Jusiak ujmuje to tak:

Tym, co się staje, jest byt aktualny, niepodzielny i przemijający. W stawaniu się bytu aktualnego nie może być przerw czy skoków, bo byt stanowi niepodzielną jednostkę istnienia. Gdyby jednostek takich w procesie nie było, wszechświat byłby mistyczną otchłanią i irracjonalnością. Jako inwariant zmiany byt aktualny „ratuje” zatem racjonalność świata. Czymś zgoła innym jest natomiast przechodzenie od jednego bytu aktualnego do drugiego lub od jednego ich nagromadzenia do drugiego. Przejście to musi być skokowe, w przeciwnym bowiem razie byt aktualny nigdy by nie mógł odpłynąć w przeszłość, co by znaczyć musiało, że czas (czy przemijanie) jest złudzeniem. (Jusiak 2006: 74-75)

Człowiek zatem niejako żyje dzięki swojej ewolucji, gdzie czas i przemijanie to droga do istnienia, a także do rozwoju. Cóż, wszak dynamizm bytu - jak pisał Karol Wojtyła (2000: 114) - ,jest zespolony z samym jego istnieniem”; wszystko, co jest aktywnością człowieka, jest jego fieri. Dla ukazania spełniania się człowieka na tych dwóch płaszczyznach i zachodzącego między nimi związku konieczne jest wniknięcie w strukturę osoby ludzkiej. Filozof ten odsłania strukturę osoby poprzez analizę świadomego działania człowieka. „Czyn jest działaniem świadomym. Kiedy mówimy »działanie świadome«, to tym wyrażeniem stwierdzamy również, że działanie to dokonuje się w sposób właściwy woli i dla niej znamienny" (tamże: 76). Można by rzec, świadomość działania wydaje się być poprzedzona jednak samym istnieniem człowieka. Tak jednak nie jest, K. Wojtyła w pewnym momencie swoich rozważań stwierdza bowiem, że człowiek zaczyna istnieć, kiedy się staje. To właśnie zaistnienie jest jakby pierwszym etapem stawania się człowieka. Nie wystarczy tu jedynie być. Podmiot poprzez swoiste dla siebie dynamizmy zmienia się, a więc staje się, czyli istnieje. Spełniony przez człowieka czyn jest czynem tego człowieka. Człowiek jest przyczyną i sprawcą własnego świadomego działania. Jak zauważa K. Wojtyła: 
[...] człowiek staje się „kimś” $i$,jakimś” nade wszystko przez swoje czyny, przez działanie świadome. Ta postać ludzkiego fieri zakłada więc sprawczość, czyli przyczynowanie właściwe osobie. Owocem tego przyczynowania, homogennym skutkiem sprawczości osobowego „ja”, jest moralność - nie jako abstrakt, ale jako najściślejsza egzystencjalna rzeczywistość związana z osobą jako właściwym swoim podmiotem. (tamże: 147).

Dalej czytamy, że „człowiek przez swoje czyny, przez działanie świadome, staje się dobrym lub złym w znaczeniu moralnym" (tamże: 147). I w tym momencie napotykamy na pojęcie wolności jako podstawowy element strukturalnego oglądu kategorii stawania się. Ten moment wolności wyłania się z samej sprawczości właściwej spełnianiu czynu człowieka, który może coś zrobić, ale nie musi; może działać, zmieniać, kreować, ale nie jest mu to nakazane. Wolność jest zatem podstawą do stawania się, nie tylko samego działania, lecz także wyznaczenia kierunku na zasadzie dychotomii dobro - zło. Musimy jeszcze zaznaczyć obecność woli ludzkiej. Wojtyła wskazuje na dwa aspekty rzeczywistości, jaką stanowi wola ludzka: wola jako właściwość osoby ludzkiej oraz wola jako władza działania (tamże: 152). W ślad za tym rozróżnieniem określa dwa znaczenia wolności woli: wolność w znaczeniu podstawowym oraz wolność w znaczeniu rozwiniętym. Wolność woli w jej podstawowym znaczeniu wiąże się z działaniem woli jako właściwości osoby. Podstawowe znaczenie wolności utożsamia autor z samostanowieniem. Samostanowienie określa jako stosunek zachodzący między wolą, będącą właściwością osoby, a osobą jako rzeczywistością pod względem własnego dynamizmu ukonstytuowaną przez wolę. Wolność woli w tym znaczeniu polega na swoistym autodeterminowaniu się osoby w każdym konkretnym działaniu. Wolność woli w znaczeniu rozwiniętym to z kolei niezależność w zakresie intencjonalnych przedmiotów chcenia.

Podobnie rzecz ujmuje Władysław Stróżewski (1987: 103), przekonując, że „dążenie do bycia innym leży u podstaw stawania się i rozwoju”. Człowiek, który się staje, musi w sobie zawierać dynamizm, który będzie wyznaczał proces stawania się, oraz musi mieć wytyczony cel - ideały, dążenia, ku którym owo stawanie się ma być ukierunkowane. Trzecim warunkiem jest dobór sposobów realizacji owego procesu stawania się, dochodzenia do celu. Człowiek stający się zawsze stoi wobec jakichś wartości, na realizację których jest niejako skazany. Ten aspekt aksjologiczny wyznacza tutaj sens owego stawania się. Człowiek transcenduje poza siebie ku jakiejś wartości i dla jakiejś wartości tak, że buduje dla siebie samego i dla innych. 


\section{STAWANIE SIĘ JAKO KATEGORIA PEDAGOGICZNA}

W tradycji pedagogicznej kategoria stawania się odnosi się do wszystkich uczestników szeroko pojętej sytuacji wychowawczej lub dydaktycznej. Stawanie się to podejmowanie i pełnienie jakiejś funkcji, czy to wychowawcy, czy też ucznia lub rodzica. Jest to proces trudny, wielostronnie uwarunkowany, a przede wszystkim długotrwały i dynamiczny, który zachodzi w trakcie nabywania wiedzy naukowej, doskonalenia umiejętności w praktyce i rozwijania cech osobowości w doświadczeniu pedagogicznym. Dotyczy on także, a może przede wszystkim, kształcenia siebie, swojej tożsamości oraz perspektyw postrzegania i interpretowania świata (Grochowalska 2014). Zasadniczo można wyróżnić tutaj dwojakie myślenie o kategorii stawania się w pedagogice. Po pierwsze, kategoria stawania się jest obecna w szeroko rozumianym procesie wychowania, ze wskazaniem na rolę sytuacji wychowawczej, którą to Krystyna Ablewicz (2003: 137) umiejscawia w optyce antropologicznej, a to wymaga wskazania na obecność w niej człowieka, a nawet - jak pisze autorka - „człowieka dorosłego i człowieka dorastającego - dziecka”. Rzecz nie jest jednak sprowadzona tylko do wnikliwej charakterystyki tych co najmniej dwóch podmiotów sytuacji, pojawia się bowiem coś więcej, kolejny element, tzw. pomiędzy, które „zawiera w sobie międzyludzką [...] przestrzeń, która tylko z pozoru może być obojętna wychowawczo" (tamże). Czy spotkanie wychowawcy z wychowankiem jest warunkiem zaistnienia owej więzi? Oczywiście nie, a dokładniej rzecz ujmując - jest niewystarczającym warunkiem. Należy wziąć pod uwagę wyjątkową, niepowtarzalną strukturę egzystencjalną każdego uczestnika tej sytuacji, a wraz z nią związane niepowtarzalne doświadczenie naturalne (zarówno wychowawcy, jak i wychowanka) oraz horyzont czasu, w którym odbywa się proces wychowania. Człowiek w procesie wychowania przekracza (lub przynajmniej powinien przekroczyć) owo bycie wychowywanym w kierunku samowychowania, autoedukacji. Wówczas jest jednostką mającą własny udział w stawaniu się, udział aktywny, celowy, świadomy oraz zgodny z przyjętymi celami (Jankowski 2006). Wychowanie to także rozwój samego wychowawcy, nauczyciela. Można też określić jego działania jako stawanie się wychowawcą. Jest to proces trwający całe życie i będący czymś więcej niż tylko byciem. Gdy spojrzymy na ten proces przez pryzmat symbolicznego interakcjonizmu, zauważymy, że polega on na przechodzeniu wychowawcy przez kolejne fazy. Warunkiem wzrostu jest umiejętność uczenia się sposobów interpretowania obiektów i zjawisk, definiowania siebie i sytuacji w sposób właściwy dla danej roli. Stawanie się jest procesem odniesionym do pewnej grupy, często bywa traktowane jako socjalizacja aspirujących do członkostwa w niej kandydatów (Hałas 2006). W toku owej socjalizacji ten, który się staje, rozwija 
własną identyfikację, a warunkiem tego rozwoju jest właśnie interakcja, w tym przyjmowanie i nabywanie określonej perspektywy poznawczej, tworzenie i odgrywanie roli, a więc wytwarzanie koncepcji działań zawodowych i sposobu ich prowadzenia (Marciniak 2008; Perry 2000).

Kategoria stawania się może być analizowana również przez pryzmat wychowania jako kształtowania się tożsamości współczesnego człowieka w warunkach wielokulturowości i międzykulturowości (Nikitorowicz 2018). Zdaniem Wojciecha Burszty (2008) z antropologicznego punktu widzenia populacje ludzkie od zarania dziejów były wielokulturowe, zarówno poprzez występowanie różnych kultur, odrębnych grup religijnych i etnicznych, jak i z uwagi na istnienie norm i wartości społecznych regulujących ową różnorodność. Wielokulturowość to także multikulturalizm, a więc swoista ideologia, której celem jest promowanie akceptacji i dowartościowywanie wielokulturowych form życia, istotnych zwłaszcza w warunkach miejskich, w tym także działania edukacyjne na rzecz dialogu międzykulturowego. Wielokulturowość jest podstawą do zaistnienia zjawiska międzykulturowości, z naciskiem położonym na akceptację pluralizmu wartości i negowaniem promowania tylko jednej kultury - kultury narodowej.

\section{TOŻSAMOŚĆ JEDNOSTKI JAKO CIĄGŁE STAWANIE SIĘ}

Zdaniem Moniki Jaworskiej-Witkowskiej (2009) edukacja wielokulturowa i międzykulturowa spowodowała w pedagogice nowe albo często zrekonstruowane obszary poszukiwań, związanych z interpretowaniem i reinterpretowaniem, dystansem, rekonstruowaniem tożsamości o często hybrydycznych rysach i ukazywaniem jednostki swoistego pogranicza. Proces pozyskiwania tożsamości jest zawsze zjawiskiem dynamicznym, jest wynikiem dziedzictwa przeszłości, komunikowania zewnętrznego i wewnętrznego. Tożsamość to rodzaj orientacji moralnej, swoista forma rozeznania w określonej przestrzeni wartości, w której pojawiają się pytania o to, co dobre, a co złe (Taylor 2001). Tożsamość stanowi dla ludzi swoistą niepowtarzalność, odrębność, specyficzność. Co wydaje się najistotniejsze, to jednostka określa swoją tożsamość. Jak zauważa Manuel Castells (2010), człowiek może posiadać wiele tożsamości, a owa wielość często rodzi sprzeczności, mniej lub bardziej wyraźne dychotomie zarówno w prezentacji siebie, jak i w działaniu społecznym. Wprowadzając pojęcie tożsamości do nauk społecznych Erik Erikson zdefiniował ją jako trzywymiarową egzystencję człowieka: możliwości organizmu, aspiracje i szanse jednostki oraz role i kariery społeczne ofiarowane przez społeczeństwo. Autor ten koncepcję tożsamości odnosi się więc do tożsamości indywidualnej, dla której siłą psychiczną jest ego - własne ja, poprzez które następuje rozumienie samego siebie i otaczającego 
świata. Tworzenie swojego ja przebiega w czasie i w dialogu z innymi ludźmi, dzięki czemu tożsamość jest otwarta i nigdy nie jest ostateczna. Jednak gdyby nie tożsamość społeczna, nie byłoby tożsamości indywidualnej, ponieważ to ona daje szansę rozpoznawania tożsamości indywidualnej.

Jerzy Nikitorowicz (2003), analizując typy tożsamości człowieka, współczynnikiem różnicowania uczynił tożsamość wielopłaszczyznową, kreowaną w wymiarze poziomym (diachronicznym - zmiennym) i pionowym (warstwowym, nakładającym się kolejno, głównie na bazie rdzennych wartości). W tak kreowanej tożsamości autor wyróżnił trzy zakresy:

1) tożsamość dziedziczona (społeczno-kulturowa, etnocentryczna),

2) tożsamość jednostkowa (osobowa),

3) tożsamość ustawicznie kształtowana (kulturowa, wielokulturowa, międzykulturowa).

Wymienione zakresy tożsamości bazują na transmisji kulturowej, aktywności jednostki lub grupy, dialogu, realizacji wartości. Tożsamość ustawicznie kształtowana, a więc będąca in statu nascendi (w procesie stawania się), odbywa się na pograniczu kultur, gdzie jednostka dokonuje wewnętrznego dialogu ze sobą i wygrywa u niej przekonanie, że tylko w interakcji z Innym może się doskonalić i uczyć odpowiedzialności. Ten Inny ma często całkiem odmienny system wartości, wyznanie, język czy kulturę. Można to zanegować, wykazać obojętność, ale można też doświadczać tej różności i inności poprzez życie razem, otwarcie na poznanie, pomoc, współdziałanie. Hybrydowa tożsamość jest mozaiką wielu wartości, zarówno tych dziedziczonych w spadku kultury własnej, jak i tych poznawanych, definiowanych i urzeczywistnianych (Ostrowska 2006). Refleksyjne określenie tożsamości wymaga odniesienia do sfery aksjologii, stąd światopoglądowy (kulturalistyczny) model tożsamości skłania do odejścia od pojęcia interakcji i posługiwania się innymi pojęciami, takimi jak: wartość, wzór kultury lub etos (Ogrodzka-Mazur 2007). Kształtowanie tożsamości człowieka jest procesem niekończącym się, dynamicznym, zmiennym kontekstualnie, nastawionym w dużej mierze na przyszłość, wielokierunkowym, ponadnarodowym, ale jest też twórczym wysiłkiem podmiotu, niwelującym napięcia i sprzeczności pomiędzy elementami odziedziczonymi, wynikającymi z uwarunkowań społecznych i identyfikacji z osobami znaczącymi, symbolami i wartościami rdzennymi, a elementami zmiennymi, nabywanymi, wynikającymi z interakcji oraz doświadczeń uczestnictwa w kulturze i strukturach społecznych, z przyswajanych i uznawanych norm i wartości. 


\section{POGRANICZE I CZŁOWIEK POGRANICZA}

Pogranicze to termin-klucz współczesnej humanistyki. Rozumiane szeroko (biorąc pod uwagę zarówno jego aspekt geograficzny, kulturowy, jak i filozoficzny), dotyczy wielu paradygmatów współczesnej nauki. Pogranicze zatem to nie tylko miejsce, lecz także stan świadomości.

Pogranicze stanowi istotny wyznacznik współczesnej kultury, ponieważ samo przebywanie w kulturze mierzy się zdolnością bycia pogranicznym, a konstruowane wówczas systemy wartości stanowią połączenie wartości zaczerpniętych z różnych systemów kulturowych (Nikitorowicz 2017). Kultura pogranicza jest zawsze bardziej urozmaicona i bogatsza od kultur centralnych, ponieważ zróżnicowane środowisko to także wiele źródeł kultur, a wielość wartości pozwala na spotkanie z barwnością i odmiennością. To nie jest utrata własnej tożsamości, lecz wzbogacanie jej poprzez wybór elementów z innej kultury; to dokonywanie ciągłych zmian w sobie, podejmowanie wyzwania zrozumienia i interpretacji odmienności. Jest to zatem tożsamość wielowarstwowa, choć bywa często strzępiasta, hybrydowa (Nikitorowicz 2019).

W myśli filozoficznej pogranicze jest opisywane jako spotkanie dwóch różniących się paradygmatów, podmiotów, a co za tym idzie w kontekst owej problematyki wpisuje się każdy dyskurs podejmujący zagadnienie dotyczące relacji Ja - Ty (Inny). Relacja interpersonalna jest tutaj nacechowana dialogiem i polifonicznością, a układ tworzy swoiste pomiędzy, pomimo odmiennych światopoglądów, tradycji i wartości (Orłowski 2016).

W perspektywie ontologicznej pogranicze „wyłania się jako teren osobny, choć bliski jednemu i drugiemu sąsiadowi, a zatem stanowiący nie tylko przedmiot sporu strukturalnego, zda się wciąż nierozstrzygniętego, ale też względnie niezależny teren faktycznego odgraniczenia" (Lipiec 2013). Jest ono efektem swoistej dynamiki dziejowej jako swoista konfrontacja często skrajnie odmiennych jakościowo grup, które za wszelką cenę próbują zachować swoją odmienność. W ten sposób na przestrzeni czasu tworzy się zręb czegoś zupełnie nowego, oryginalnego, ale o cechach często niedomkniętej, porozrywanej, strzępiastej nowości.

Lech Witkowski (2000) zaproponował interdyscyplinarną perspektywę ujęcia kategorii pogranicza, dokonując reinterpretacji filozoficzno-estetycznej koncepcji Michaiła Bachtina na potrzeby refleksji pedagogicznej. Autor ten uwzględnił cztery aspekty (rozumienia) ontologii „bycia między”:

[...] może to być bowiem pogranicze w rozumieniu terytorialnym, może być przesycone charakterem interakcyjnym, może być dookreślane w kontekście relacji (różnic i przeciwieństw) i wreszcie może być ono generowane przez ambiwalentny 
status uczestniczących w nim członków sytuacji kulturowej, podmiotów czy kategorii deskryptywnych. (tamże: 40)

Pogranicze rozumiane jest tutaj w aspekcie przestrzennym, kulturowo-społecznym oraz kulturowo-osobowym i dotyka przekształcania się granic osobowego rozwoju jednostki, rozwoju jej samoświadomości i samowiedzy, który dokonuje się w procesie dialogowego kontaktu z Innym. Ważnym dla całości problematyki pogranicza pojęciem wprowadzonym przez Bachtina jest niewspółobecność, dookreślanym z punktu widzenia trzech płaszczyzn: etycznej, estetycznej i kulturowej. W pierwszym przypadku mamy do czynienia ze spotkaniem dwóch podmiotów, podczas którego dochodzi do wstępnej empatii (wczucia w sytuację, światopogląd partnera dialogu), a następnie do powrotu do własnej świadomości i nadania nowego sensu przeżyciu innego (Bachtin 1986). Bachtin przekonuje, że nie zrozumiemy drugiego człowieka w sposób, który sam siebie rozumie, ale treść spotkania, pozostająca na pograniczu naszej możliwości, rodzi konstruktywny odzew, np. chęć pomocy czy wsparcia. Człowiek pogranicza jest otwarty na spotkanie, na to co nowe i różniące się od niego, dzięki czemu może także wzbogacić swoją osobowość.

W drugim aspekcie niewspótobecność dotyczy kwestii wyłącznie estetycznych. Rodzaje relacji międzyludzkich można porównać metaforycznie do powieści - tej o charakterze polifonicznym i tej określanej jako homofoniczna. Pierwsza wskazuje na relacje otwarte i partnerskie, zmierzające do poznania (i samopoznania), druga zaś to typ układów dogmatycznych, nastawionych na "nawracanie” i wskazywanie właściwej drogi. Bachtin dookreśla pierwszy rodzaj relacji jako etyczne, nacechowane odpowiedzialnym podejściem do drugiego człowieka (Handler 2009).

Trzecim aspektem, na płaszczyźnie którego mamy do czynienia z problematyką niewspółobecności, jest sfera kulturowa, przy założeniu, że „cudza kultura odsłania się dopiero w oczach innej kultury” (Bachtin 1986: 474).

Tutaj to dwie różniące się kultury najwięcej mogą zyskać na wzajemnym spotkaniu, na swoistym oglądzie tego, co obce (inne) z własnej perspektywy światopoglądowej. To właśnie dzięki Innemu i jego światoodczuciu (kulturze) można spojrzeć na siebie oczami drugiego, a tym samym w pełni odpowiedzieć na fundamentalne pytanie o to, kim jestem i kim się staję. Na pograniczu etnicznym, religijnym, światopoglądowym, gdzie ma miejsce wspólna egzystencja zróżnicowanych grup społecznych, poszczególne jednostki mają okazję do głębszego przeżywania swojego człowieczeństwa (Orłowski 2016: 40).

Zbigniew Kurcz zdefiniował swoisty profil cech człowieka pogranicza, wśród których znajdują się otwartość i krytycyzm wobec obcych. Jest on: 
[...] bardziej przywiązany lub obojętny do wartości własnej grupy narodowej niż mieszkańcy centrum. Człowiek pogranicza jest bardziej zaradny i przedsiębiorczy (jeśli dotyczy to nawet aktywności o patologicznym charakterze), bardziej innowacyjny i skłonny do akceptacji idei i nowinek napływających z zewnątrz, szczególnie wówczas, gdy dostrzega ich pozytywne konsekwencje dla siebie. (Kurcz 2008: 20)

Zbiór cech charakteryzujących człowieka pogranicza wpisuje się w profil człowieka nowoczesnego, wyemancypowanego z krępujących więzi społecznych, który zarazem dba o siebie i swoją kondycję socjoekonomiczną. To człowiek indywidualista, który swoją tożsamość buduje samodzielnie, kształtując ja na własnych wyborach dokonywanych w obrębie zasobów społeczno-kulturowych, niezwiązanych bezpośrednio z grupami społecznymi.

Jerzy Nikitorowicz podpowiada, kim ma być człowiek pogranicza, rysując jego dość wyrazisty obraz jako tego, który:

- potrafi uwolnić się z jednoprojektowych dogmatów ograniczających wyjście poza ustalone granice,

- upomina się o podmiotowość, uwalnia się z uprzedmiotowienia,

- odbudowuje i tworzy alternatywy, przywołuje zapomniane obszary myślenia i badań,

- respektuje prawo istnienia obok, na równych prawach, uwalnia się od ksenofobii i megalomanii,

- potrafi znaleźć się w układzie polifonicznym, który polega na łączeniu w jedną muzyczną całość kilku jednocześnie brzmiących samodzielnych melodii,

- jest świadomy różnic, ale i podobieństw, propaguje różne formy interakcji, odżegnuje się od budowania wspólnoty na koncepcji obcości i wrogości,

- nie dopuszcza do izolacji kulturowej, nie zrywa naturalnych więzi,

- pozyskuje nowe obszary myślenia i refleksji,

- przekształca koncepcję „swój - obcy”, traktując tym samym odmienność i inność nie w kategoriach zagrożenia, wrogości, nienormalności, ale coś interesującego, stymulującego, fascynującego, pomocnego w rozumieniu człowieka i świata. (Nikitorowicz 1996: 338)

Wydaje się, że to właśnie u człowieka pogranicza kształtuje się tożsamość otwarta, aktywna, tożsamość międzykulturowa. 


\section{STAWANIE SIĘ CZŁOWIEKA POGRANICZA W PROCESIE EDUKACJI MIĘDZYKULTUROWEJ}

W edukacji międzykulturowej wskazuje się, że jej zasadnicze cele i powinności mocno wiążą się ze sferą wartości. Zwraca się przy tym uwagę na proces przemiany, która powinna - także dzięki działaniom pedagogicznym - zachodzić w osobie przyjmującej za własne cele i powinności edukacji międzykulturowej, dążącej do ich urzeczywistniania i z tej racji ćwiczącej się w sprawnościach niezbędnych do uczestniczenia w relacjach międzykulturowych. Pogranicze to często stan chaosu, zagubienia, anomii i to właśnie zdaniem Nikitorowicza (2014) winno być celem edukacji, czyli kształtowanie takiego człowieka pogranicza, który dokonuje ustawicznych zmian w sobie, opuszcza centrum, wychodzi na pogranicza myślowe i badawcze, próbując spojrzeć z boku lub z drugiej strony na kulturę dominującą, dostrzega uwikłania i chaos i jest przygotowany do wyboru wartości.

Aksjologia międzykulturowości opiera się na szacunku dla różnic etnicznych, rasowych i kulturowych danego społeczeństwa oraz na tolerancji i nieustannym procesie dialogu kultur. Sprzyja kształtowaniu tożsamości mocno zakorzenionej w „ojczyźnie lokalnej”, a jednocześnie otwartej i poszukującej, ciągle doskonalącej się, stającej się po prostu.

Pogranicze współcześnie staje się więc naturalnym środowiskiem człowieka, rozumianym jako „leżący poza centrum obszar zróżnicowań, inności i odmienności, gdzie można porównywać, odkrywać, wykazywać zdziwienie, negocjować i prowadzić dialog" (tamże: 177).

Świadomość odrębności kulturowej zarówno wyzwala u człowieka pogranicza poczucie tożsamości społecznej i kulturowej (rodzinnej, religijnej, wyznaniowej, etnicznej), jak i powoduje zagrożenie, utratę poczucia bezpieczeństwa, lęk przed nietolerancją grupy dominującej. Rodzi się zatem wyraźna potrzeba dyskusji oraz opracowania spójnych propozycji programowych i realizacyjnych edukacji aksjologicznej, wielo- i międzykulturowej, jak również przygotowania kompetentnych pedagogów, których wiedza i umiejętności, w szczególności w określonych zakresach, umożliwią:

- przejście od tożsamości jednowymiarowej do rozproszonej i wielokulturowej; wybór wartości i tożsamości zgodnie ze współczynnikiem humanistycznym,

- przejście od monologu do dialogu kultur, od dominacji stereotypów i uprzedzeń do wzajemnego zrozumienia, otwarcia na świat, do negocjacji i dbałości o wspólny spadek kultury pogranicza, 
- przejście od wychowania doktrynalnego, adaptacyjnego, przedmiotowego do wychowania szanującego inność, podmiotowego i przyjaznego (Nikitorowicz 2017).

Człowiek pogranicza ma specyficzną tożsamość, zmienną, o charakterze procesualnym, a jego profil wpisuje się w rys człowieka nowoczesnego, wyemancypowanego z krępujących więzi społecznych, który zarazem dba o siebie i swoją kondycję socjoekonomiczną. Blisko mu do wzoru indywidualisty, który swoją tożsamość buduje samodzielnie, opierając ja na własnych wyborach, dokonywanych w obrębie szerokich zasobów społeczno-kulturowych, niezwiązanych bezpośrednio i wprost z grupami realnej przynależności jednostki (Machaj 2016). Podstawową wykładnią i jednocześnie źródłem stawania się człowieka pogranicza jest dynamizm. Jest to zresztą charakter życia człowieka, droga ku czemuś, ruch, zmiana, rozwój. Przekraczanie własnych horyzontów, w których jednostka czasem jest za bardzo zakorzeniona, to droga do optymalnego rozwoju, a rozwój człowieka to wielość, różnorodność, to sięganie do tego, co niekoniecznie jest źródłem naszego poznania, to bycie sobą, ale w różnych wcieleniach kulturowych i aksjologicznych. Horyzontalny wariant dynamizmu jest nacechowany dwoistością, ambiwalencją, oscylowaniem wokół skrajności, ale może też posiadać inny wymiar - wertykalny - i wówczas dynamizm człowieka wymaga widzenia perspektywy diachronicznej, skokowej zmiany, poszukiwania drogi ku lepszemu. Stawanie się człowieka pogranicza odnosi się do przyszłości, choć jego źródła tkwią w dzisiejszym świecie; jest wyzwaniem dla edukacji międzykulturowej, a zwłaszcza dla tzw. aksjologii międzykulturowości. Dotyczy to konstruowania systemu edukacyjnego orientowanego na inicjowanie i realizowanie swoistego dialogu międzykulturowego, w ramach którego może następować kształtowanie postaw otwartości i rozumienia oraz uzyskiwanie porozumienia $\mathrm{z}$ innymi kulturami.

\section{BIBLIOGRAFIA}

Ablewicz, K. (2003). Teoretyczne i metodologiczne podstawy pedagogiki antropologicznej. Studium sytuacji wychowawczej. Kraków: Wydawnictwo UJ.

Bachtin, M. (1986). Estetyka twórczości słownej. Warszawa: PIW.

Burszta, W. (2008). Od wielokulturowości do międzykulturowości, z monokulturą w tle. Kultura Współczesna, nr 2(56), 19-36.

Castells, M. (2010). Społeczeństwo sieci. Warszawa: Wydawnictwo Naukowe PWN.

Grochowalska, M. (2014). Dylematy nowicjusza. Konteksty stawania sie nauczycielem edukacji przedszkolnej. Edukacja Elementarna, nr 31, 27-40.

Grzmot-Bilski, G.J. (1996). Idea racjonalności w filozofii A.N. Whiteheada. Bydgoszcz: Wydawnictwo Uczelniane Wyższej Szkoły Pedagogicznej. 
Hałas, E. (2006). Interakcjonizm symboliczny. Warszawa: Wydawnictwo Naukowe PWN. Handler, W. (2009). Etyka podmiotowej kreacji u Bachtina i Lacana. W: D. Ulicka (red.), Ja-inny. Wokót Bachtina (s. 5-23). Krakow: Universitas.

Jankowski, D. (2006). Edukacja wobec zmiany. Toruń: Wydawnictwo Adam Marszałek. Jaworska-Witkowska, M. (2009). Ku kulturowej koncepcji pedagogiki. Kraków: Oficyna Wydawnicza Impuls.

Jusiak, J. (2006). Pojęcie czasu u Jamesa i Whiteheada. W: B. Ogrodnik, K.W. Gródka (red.), Studia Whiteheadiana (T. 2). Kraków: Wydawnictwo PAT.

Kurcz, Z. (2008). Przedmiot socjologii pogranicza w świetle polskich doświadczeń. W: Z. Kurcz (red.), Polskie pogranicza w procesie przemian (T. 1; s. 19-29). Wałbrzych: Wydawnictwo WWSZiP.

Lipiec, J. (2013). Filozofia pogranicza, pogranicze filozofii. Zeszyty Naukowe Politechniki Śląskiej, nr 65, 197-206.

Machaj, I. (2016). Pogranicze a tożsamość. Ile zmienności, ile stabilności? Pogranicze. Studia Społeczne, t. 27, cz. 1,61-75, DOI: https://doi.org/10.15290/pss.2016.27.01.04.

Magee, B. (2000). Wyznania filozofa. Warszawa: Wydawnictwo Prószyński i S-ka.

Marciniak, Ł.T. (2008). Stawanie się nauczycielem akademickim. Analiza symboliczno-interakcjonistyczna. Przegląd Socjologii Jakościowej, t. 4(2), 1-141.

Nikitorowicz, J. (1996). Edukacja regionalna, wielokulturowa i międzykulturowa. W: H. Kwiatkowska, Z. Kwieciński (red.), Demokracja a oświata, kształcenie $i$ wychowanie (s. 335-344). Toruń: Polskie Towarzystwo Pedagogiczne.

Nikitorowicz, J. (2003). Typy tożsamości człowieka w społeczeństwie zróżnicowanym kulturowo. Chowanna, nr 1, 50-66.

Nikitorowicz, J. (2014). Wielokulturowość - pogranicze - człowiek pogranicza. Ku paradygmatowi wspołistnienia, zachowania i kreowania pokoju. Drohiczyński Przeglad Naukowy, nr 6/24, 171-189.

Nikitorowicz, J. (2017). Etnopedagogika w kontekście wielokulturowości i ustawicznie ksztattującej się tożsamości. Kraków: Oficyna Wydawnicza Impuls.

Nikitorowicz, J. (2018). Edukacja międzykulturowa w procesie wspierania rozwoju tożsamości w warunkach wielokulturowości. Kultura i Edukacja, nr 3(121), 55-68.

Nikitorowicz, J. (2019). Hybrydowa tożsamość na kulturowym pograniczu - potencjał i problem osobisty i grupowy? Annales Universitatis Mariae Curie-Skłodowska. Sectio J, Paedagogia-Psychologia, vol. 32(2), 11-20, DOI: https://doi. org/10.17951/j.2019.32.2.11-22.

Ogrodzka-Mazur, E. (2007). Kompetencja aksjologiczna dzieci w młodszym wieku szkolnym. Studium porównawcze środowisk zróżnicowanych kulturowo. Katowice: Wydawnictwo Uniwersytetu Śląskiego.

Orłowski, A. (2016). Fascynacje pograniczem w dwudziestowiecznej myśli filozoficznej i antropologicznej - Bachtin, Todorov, Buber, Levinas. Pogranicze. Polish Borderlands Studies, t. 4(1), 5-23, DOI: https://doi.org/10.25167/ppbs439.

Ostrowska, U. (2006). Aksjologiczne podstawy wychowania. W: B. Śliwerski (red.), Pedagogika, podstawy nauk o wychowaniu (T. 1; s. 392-414). Gdańsk: GWP.

Perry, R. (2000). Teoria i praktyka. Proces stawania się nauczycielem. Warszawa: WSiP. Skarga, B. (2005). Granice historyczności. Warszawa: PIW. 
Pobrane z czasopisma Annales N - Educatio Nova http://educatio.annales.umcs.pl Data: 26/04/2023 17:13:43

Stróżewski, W. (1987). O stawaniu się człowiekiem. Zeszyty Naukowe Uniwersytetu Jagiellońskiego. Prace Pedagogiczne, nr 6, 103-110.

Tatarkiewicz, W. (1998). Historia filozofii. Warszawa: Wydawnictwo Naukowe PWN.

Taylor, C. (2001). Źródta podmiotowości. Narodziny tożsamości nowoczesnej. Warszawa: Wydawnictwo Naukowe PWN.

Witkowski, L. (2000). Uniwersalizm pogranicza. O semiotyce kultury Michała Bachtina w kontekście edukacji. Torun: Wydawnictwo Adam Marszałek.

Wojtyła, K. (2000). Osoba i czyn oraz inne studia antropologiczne. Lublin: Wydawnictwo Towarzystwa Naukowego.

Żelazny, M. (2000). Heglowska filozofia ducha. Warszawa: Wydawnictwo Instytutu Filozofii i Socjologii PAN. 